\title{
Micro Fine Sized Palm Oil Fuel Ash Produced Using a Wind Tunnel Production System
}

\author{
R. Ahmadi, ${ }^{1}$ N. Zainudin, ${ }^{1}$ I. Ismail, ${ }^{1}$ M. A. Mannan, ${ }^{1}$ and A. S. Z. Abidin ${ }^{2}$ \\ ${ }^{1}$ Department of Civil Engineering, University Malaysia Sarawak, 94300 Samarahan, Sarawak, Malaysia \\ ${ }^{2}$ Department of Mechanical and Manufacturing Engineering, University Malaysia Sarawak, 94300 Samarahan, Sarawak, Malaysia
}

Correspondence should be addressed to R. Ahmadi; araudhah@unimas.my

Received 20 March 2016; Accepted 11 August 2016

Academic Editor: Sverak Tomas

Copyright (C) 2016 R. Ahmadi et al. This is an open access article distributed under the Creative Commons Attribution License, which permits unrestricted use, distribution, and reproduction in any medium, provided the original work is properly cited.

\begin{abstract}
Micro fine sized palm oil fuel ash (POFA) is a new supplementary cementitious material that can increase the strength, durability, and workability of concrete. However, production of this material incurs high cost and is not practical for the construction industry. This paper investigates a simple methodology of producing micro fine sized POFA by means of a laboratory scale wind tunnel system. The raw POFA obtained from an oil palm factory is first calcined to remove carbon residue and then grinded in Los Angeles abrasion machine. The grinded POFA is then blown in the fabricated wind tunnel system for separation into different ranges of particle sizes. The physical, morphological, and chemical properties of the micro fine sized POFA were then investigated using Laser Particle Size Analyser (PSA), nitrogen sorption, and Scanning Electron Microscopy with Energy Dispersive X-Ray (SEM-EDX). A total of $32.1 \%$ micro fine sized POFA were collected from each sample blown, with the size range of 1-10 micrometers. The devised laboratory scale of wind tunnel production system is successful in producing micro fine sized POFA and, with modifications, this system is envisaged applicable to be used to commercialize micro fine sized POFA production for the construction industry.
\end{abstract}

\section{Introduction}

The palm oil industries in Malaysia, being the second largest palm oil producer in the year 2010, are producing up to 4.5 million tons of waste per year $[1,2]$. This solid waste or byproduct, known as palm oil fuel ash (POFA), is abundant and if not disposed properly may contribute to serious environmental problem which could be harmful to mankind [3].

In recent years, POFA is found to have high potentials as a new alternative material for concrete and construction industry since it possesses pozzolanic properties [3-8]. The pozzolanic reaction between silica oxides and calcium hydroxide during the hydration process in concrete will produce calcium silicate hydrate, a gel compound that supports the production of stronger and denser concrete $[9,10]$. Utilizing POFA as a supplementary cementitious material is anticipated to produce concrete with properties of high strength with resistance to adverse environment condition.

In the earlier studies, POFA had been claimed as not suitable for replacing cement in concrete for more than $10-20 \%$ by mass of cement if high compressive strength concrete is to be achieved $[3,11,12]$. Nevertheless, another study pointed out that $40 \%$ replacement of cement using micro fine size POFA contributes to high strength concrete achieving compressive strength up to $112 \mathrm{MPa}$ which is $14 \%$ higher than normal strength of Ordinary Portland Cement (OPC) concrete [13].

In terms of physical properties, micro fine size POFA has a lower specific gravity, smaller median particle size, and greater specific surface area $[12,14]$ which contributes to improvement of workability in fresh concrete. A study demonstrated that the finer size of POFA contributes significantly to packing effect and pozzolanic reaction in cement paste [12]. However, these factors depend on the curing ages and the percentage of fine size POFA as cement replacement material in concrete.

Until today, an economical way of producing micro fine size POFA is not well established. Due to the significant contribution of micro fine size POFA as supplementary cementitious material, a new approach to produce this material using a wind tunnel system is carried out. This method is simple and economical in order to separate the micro fine size POFA into 


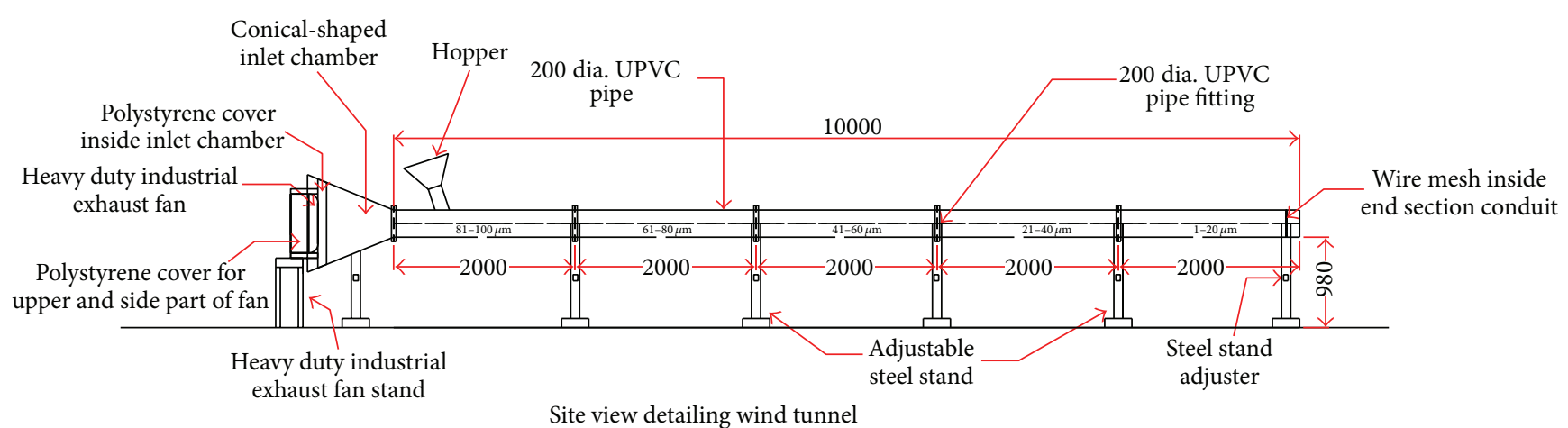

FIgURE 1: 2D schematic drawing of the finalized wind tunnel production system.

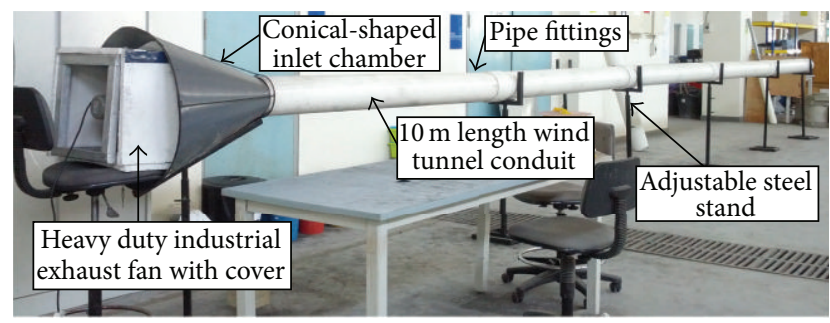

FIGURE 2: Side view of the wind tunnel production system setup.

a different range of size. This research focuses on the optimum grinding and treatment process in producing micro fine size POFA as well as investigating the physical and morphological properties of micro fine size POFA which can affect the strength, workability, and hardened concrete properties.

\section{Experimental Procedures}

2.1. Materials. The main material used in this research is POFA while cement and fly ash are used as control materials. The raw material of POFA was obtained from Rimbunan Hijau (RH) Palm Oil Mill, Lundu, in Sarawak, Malaysia. Cement used in this research is Ordinary Portland Cement (OPC) type 1 which is produced by a cement producer company, Cahya Mata Sarawak (CMS) Sdn. Bhd.

2.2. Treatment on POFA. Initially, $20 \mathrm{~kg}$ of raw POFA is dried in oven with temperature of $110 \pm 5^{\circ} \mathrm{C}$ for 24 hours to remove moisture content. Then, the raw POFA is machine-grinded using the Los Angeles abrasion machine for a total duration of 24 hours.

2.3. Fabrication of Wind Tunnel. The fabricated wind tunnel system comprises six essential components. As shown in Figures 1-4, the components are heavy duty industrial exhaust fan and conical-shaped inlet chamber as wind source and wind shield, hopper as the opening to insert POFA into the conduit, 10-meter unplasticised polyvinyl chloride (UPVC) pipe complete with adjustable stand which acts as the wind tunnel conduit, and pipe fittings as pipe connecter

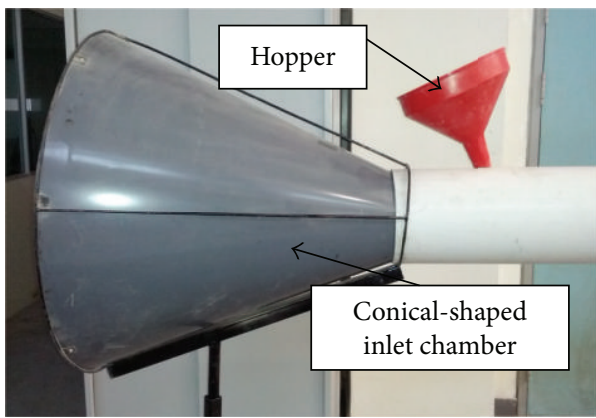

FIGURE 3: Location and position of hopper.

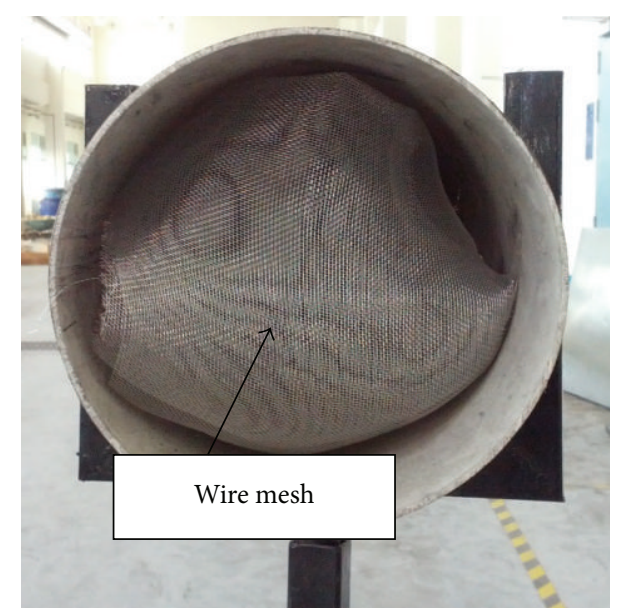

FIGURE 4: Location of wire mesh inside the conduit.

and section breaker and also wire mesh to trap the micro fine size POFA from flying out of the conduit $[8,15]$.

2.4. Micro Fine Sized POFA Separation and Analyses. This wind tunnel system uses forced air as wind to carry the ground POFA in a $10 \mathrm{~m}$ segmental tunnel which consists of 5 connected segments at $2 \mathrm{~m}$ length each. A larger size POFA is expected to settle down in the front part of the tunnel while micro fine sized POFA (with a lighter mass) is expected to be blown until the end of the tunnel. POFA at 
TABLE 1: Samples sizes from PSA analyses.

\begin{tabular}{lccc}
\hline Sample & $\begin{array}{c}\text { Diameter at } \\
50 \%[\mu \mathrm{m}]\end{array}$ & $\begin{array}{c}\text { Specific } \\
\text { surface area } \\
{\left[\mathrm{m}^{2} / \mathrm{g}\right]}\end{array}$ & $\begin{array}{c}\text { Percentage } \\
(\%) \\
\text { collected }\end{array}$ \\
\hline OPC & 13.41 & 1.348 & - \\
FA & 8.64 & 2.173 & - \\
POFA $(2 \mathrm{~m})$ & 13.28 & 2.011 & 56.95 \\
POFA $(4 \mathrm{~m})$ & 10.84 & 2.569 & 21.60 \\
POFA $(6 \mathrm{~m})$ & 8.71 & 2.587 & 5.95 \\
POFA $(8 \mathrm{~m})$ & 7.29 & 3.026 & 2.10 \\
POFA $(10 \mathrm{~m})$ & 5.37 & 3.950 & 2.45 \\
\hline
\end{tabular}

different sections of the tunnel are collected and analysed using Laser Particle Size Analyser (PSA), nitrogen sorption, and Scanning Electron Microscopy with Energy Dispersive $\mathrm{X}$-Ray (SEM-EDX). Prior to these tests, the collected POFA at each segment of the wind tunnel are calcined in a muffle furnace at $500^{\circ} \mathrm{C}$ to remove excess carbon. Ordinary Portland Cement (OPC) and fly ash (FA) are also used as control samples.

\section{Results and Discussions}

3.1. Particle Size Analyses. Particle size analyses estimate the micro fine sized POFA based on the diameter of spherical particles whereas, for nonspherical particles, the horizontal and vertical projections of the particles are measured. As shown in Table 1 , the median diameter $\left(d_{50}\right)$ of POFA collected at all sections of wind tunnel is decreasing from $13.28 \mu \mathrm{m}$ to $10.84 \mu \mathrm{m}, 8.71 \mu \mathrm{m}, 7.29 \mu \mathrm{m}$, and finally $5.37 \mu \mathrm{m}$ at the final section of the wind tunnel. By comparing $d_{50}$ size of POFA with OPC and FA, POFA at the very end section of wind tunnel has the smallest diameter. Hence, these results showed that micro fine sized POFA $(1-10 \mu \mathrm{m})$ have higher surface area compared to normal OPC and FA. Overall, a total of 32.1\% micro fine sized POFA were successfully collected from each sample blown through the wind tunnel system, with the size range of $1-10 \mu \mathrm{m}$. The percentage of loss during the test was $10.95 \%$.

3.2. Nitrogen Sorption $\left(B E T_{N 2}\right)$ Analysis. Nitrogen sorption $\mathrm{BET}_{\mathrm{N} 2}$ analysis is widely used to examine the specific surface area of POFA $[12,14,15]$. The $\mathrm{BET}_{\mathrm{N} 2}$ analysis estimates the surface area of micro fine sized POFA based on the pore size of the particle.

As shown in Table 2, the average pore radius is increasing from $0.000668 \mu \mathrm{m}$ to $0.0008008 \mu \mathrm{m}$. Since the pore radius becomes larger at the end section of the wind tunnel, this indicates that the particle size had become smaller because there are more nitrogen gas molecules that can fill in the pore at the particle surface. This result is also closely related to the total pore volume of the particles. At the end of the wind tunnel $(10 \mathrm{~m})$, the total pore volume is $0.000786 \mathrm{cc} / \mathrm{g}$ which is the highest compared to other distances and also higher than total pore volume of OPC.
3.3. Scanning Electron Microscopy (SEM) Analysis. OPC has a nonspherical particle and has an irregular shape which seems to be a stone shape. This shape leads to stronger particle interlocking and thus increases the surface friction and viscosity of cement paste [16]. On the other hand, fly ash has round, ball-shaped-like particles which vary in size while larger fly ash has more irregular and angular shapes [17]. Fly ash also can be described as having a significant proportion of particles with hollow spheres [12].

From the SEM test results, the surface morphology of POFA collected at each section was obtained and shown in Figure 5. POFA that had been collected at $2 \mathrm{~m}$ distance of wind tunnel (Figure 5(a)) shows spherical particles with irregular porous cellular shaped structure. POFA at $4 \mathrm{~m}$ distance (Figure 5(b)) is having a similar surface morphology to POFA at $2 \mathrm{~m}$ distance. However, this particle has less observable pores compared to particle at $2 \mathrm{~m}$, consistent with pore volume measured by nitrogen sorption. In Figure 5(c), the POFA particle at $6 \mathrm{~m}$ distance of the wind tunnel starts to form slightly irregular shape and has more pores compared to particle at $4 \mathrm{~m}$ distance. The particles at $8 \mathrm{~m}$ and $10 \mathrm{~m}$ distances as shown in Figures 5(d) and 5(e), respectively, are of irregular shapes and no pore is observed on the surface of these particles.

3.4. Energy Dispersive X-Ray (EDX) Analysis. Silica and calcium are considered in the EDX analysis since these two elements are crucial in cement hydration. In this analysis, mapping method was used in order to identify the chemical composition of the materials. However, only two mapping areas were chosen for each type of material that was being tested.

Results tabulated in Table 3 indicate that amongst OPC, FA, and five different distances of POFA, POFA collected at $2 \mathrm{~m}$ distance of the wind tunnel has the highest amount of silica and calcium content which are $69.59 \%$ and $14.25 \%$, respectively. POFA has the potential to serve as cement replacement material in concrete due to the high content of silica [18]. This element is beneficial in concrete production because silica oxide, $\mathrm{SiO}_{2}$, has a good abrasion resistance, electrical insulation, and high thermal stability. Thus, this condition leads to the production of high strength and more durable concrete.

Comparison of micro fine sized POFA collected at different sections of the tunnel showed that each sample collected contains different percentage of silica and calcium. The different patterns of silica and calcium content in the different micro fine sized POFA samples are influenced by the difference in number of particles scanned by EDX. However, the chemical composition of POFA samples collected at each of the distances should be almost similar since it comes from the same source.

Another important factor that is investigated in this research is if the differences in POFA particle sizes will change the percentage of the chemical composition possessed by the materials. The results tabulated in Table 3 show that the pattern of chemical composition content in the micro fine sized POFA is not affected by the particle sizes. This finding is found to be consistent with the previous studies $[12,13]$. 
TABLE 2: Size of sample from $\mathrm{BET}_{\mathrm{N} 2}$ test.

\begin{tabular}{|c|c|c|c|c|c|c|c|}
\hline Sample & OPC & Fly ash (FA) & POFA $(2 \mathrm{~m})$ & POFA $(4 \mathrm{~m})$ & POFA $(6 \mathrm{~m})$ & POFA $(8 \mathrm{~m})$ & POFA $(10 \mathrm{~m})$ \\
\hline $\begin{array}{l}\text { Average pore } \\
\text { radius }[\mu \mathrm{m}]\end{array}$ & $1.46 \times 10^{-4}$ & 0.000820 & 0.000668 & 0.000799 & 0.000965 & 0.000820 & 0.000801 \\
\hline $\begin{array}{l}\text { Average pore dia. } \\
{[\mu \mathrm{m}]}\end{array}$ & 0.000291 & 0.001639 & 0.001335 & 0.001598 & 0.001930 & 0.001632 & 0.001602 \\
\hline $\begin{array}{l}\text { Total pore volume } \\
{[\mathrm{cc} / \mathrm{g}]}\end{array}$ & 0.00027 & 0.00091 & 0.00533 & 0.00597 & 0.00073 & 0.000787 & 0.000786 \\
\hline $\begin{array}{l}\text { Specific surface } \\
\text { area }\left[\mathrm{m}^{2} / \mathrm{g}\right]\end{array}$ & 3.730 & 2.221 & 15.967 & 18.314 & 12.367 & 19.196 & 19.618 \\
\hline
\end{tabular}
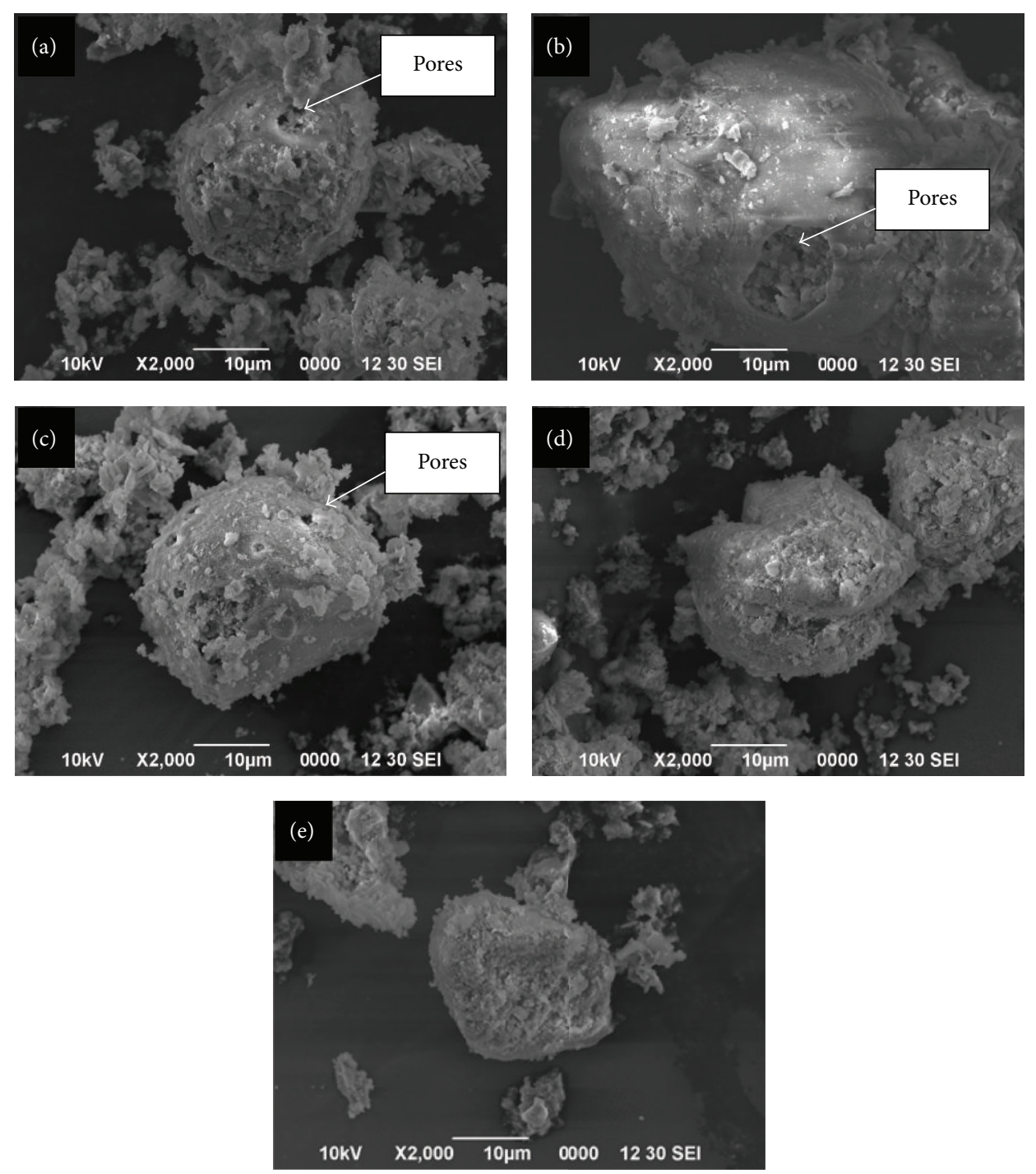

Figure 5: SEM images of POFA collected at distances (a) $2 \mathrm{~m}$, (b) $4 \mathrm{~m}$, (c) $6 \mathrm{~m}$, (d) $8 \mathrm{~m}$, and (e) $10 \mathrm{~m}$ of the wind tunnel.

\section{Conclusion and Recommendation}

Based on the results obtained from the current laboratory investigation, the following conclusions can be drawn:

(i) The final product of the wind tunnel production system in this research is able to produce $32.1 \%$ micro fine sized POFA from each sample blown. PSA tests recorded that the size of micro fine sized POFA range between 1 and $10 \mu \mathrm{m}$ with the largest specific surface area of $3.950 \mathrm{~m}^{2} / \mathrm{g} . \mathrm{BET}_{\mathrm{N} 2}$ test gives average pore radius of $0.000820 \mathrm{~m}^{2} / \mathrm{g}$ with specific surface area of $19.196 \mathrm{~m}^{2} / \mathrm{g}$. 
TABLE 3: Chemical composition of each sample from EDX analysis.

\begin{tabular}{|c|c|c|c|c|}
\hline \multirow{3}{*}{ Material } & \multicolumn{2}{|c|}{ Silica } & \multicolumn{2}{|c|}{ Calcium } \\
\hline & Mapping area A & Mapping area B & Mapping area A & Mapping area B \\
\hline & Mass as oxide (\%) & Mass as oxide (\%) & Mass as oxide (\%) & Mass as oxide (\%) \\
\hline $\mathrm{OPC}$ & 16.24 & 19.40 & 70.11 & 73.69 \\
\hline Fly ash & 45.21 & 48.02 & - & 2.33 \\
\hline POFA at $2 \mathrm{~m}$ & 50.08 & 69.59 & 12.90 & 14.25 \\
\hline POFA at $4 \mathrm{~m}$ & 23.79 & 31.34 & 4.53 & 10.03 \\
\hline POFA at $6 \mathrm{~m}$ & 35.34 & 45.21 & 8.97 & 5.70 \\
\hline POFA at $8 \mathrm{~m}$ & 30.31 & 26.82 & 4.57 & 1.52 \\
\hline POFA at $10 \mathrm{~m}$ & 41.48 & 28.27 & 7.44 & 7.13 \\
\hline
\end{tabular}

(ii) The Scanning Electron Microscopy with Energy Dispersive X-Ray (SEM-EDX) tests showed the surface morphology of micro fine sized POFA collected from the wind tunnel system. High silica content is also found in the chemical composition of the micro fine sized POFA.

The results obtained indicate that the wind tunnel production system is successful in producing micro fine size POFA and this system is envisaged applicable for use in the industry provided further modification is carried out in future work to increase the efficiency of this device.

\section{Competing Interests}

The authors declare that they have no competing interests.

\section{Acknowledgments}

This research is funded by Osaka Gas Foundation in Cultural Exchange (OGFICE) Research Grant session 2014/2015.

\section{References}

[1] Y. Zarina, A. M. M. Mustafa Al-Bakri, H. Kamarudin, I. K. Nizar, and A. R. Rafiza, "Review on the various ash from palm oil waste as geopolymer material," Reviews on Advanced Materials Science, vol. 34, no. 1, pp. 37-43, 2013.

[2] N. Abdullah and F. Sulaiman, "The oil palm wastes in Malaysia," in Biomass Now-Sustainable Growth and Use, M. D. Matovic, Ed., chapter 3, pp. 75-100, InTech, Rijeka, Croatia, 2013, http:// www.intechopen.com/books/biomass-now-sustainable-growthand-use/the-oil-palm-wastes-in-malaysia.

[3] J.-H. Tay and K.-Y. Show, "Utilization of ashes from oil-palm wastes as a cement replacement material," Water Science and Technology, vol. 34, no. 11, pp. 185-192, 1996.

[4] K. Abdullah, M. W. Hussin, F. Zakaria, R. Muhamad, and Z. Abdul Hamid, "POFA: a potential partial cement replacement material in aerated concrete," in Proceedings of the 6th Asia Pacific Structural Engineering and Construction, Kuala Lumpur, Malaysia, 2006.

[5] N. M. Altwair, M. Azmi, M. Johari, and S. F. S. Hashim, "Strength activity index and microstructural characteristics of treated palm oil fuel ash," International Journal of Civil and Environmental Engineering, vol. 11, no. 5, pp. 85-92, 2011.
[6] A. S. M. Abdul Awal and M. Warid Hussin, "Effect of palm oil fuel ash in controlling heat of hydration of concrete," Procedia Engineering, vol. 14, pp. 2650-2657, 2011.

[7] N. M. Altwair and S. Kabir, "Palm Oil Fuel Ash (POFA): an environmentally-friendly supplemental cementitious material for concrete production," in Proceedings of the International RILEM Conference on Material Science, W. Brameshuber, Ed., pp. 113-126, RILEM Publications SARL, 2010.

[8] N. Zainudin, R. Ahmadi, and M. D. Mannan, "Production of micro fine size Palm Oil Fuel Ash (POFA) pozzolan using wind tunnel production system," in Proceedings of the MATEC, 2015.

[9] M. H. Ahmad, R. C. Omar, M. A. Malek, M. N. Nor, and S. Thiruselvam, "Compressive strength of palm oil fuel ash concrete," in Proceedings of the International Conference on Construction and Building Technology (ICCBT'08), pp. 297-306, Kuala Lumpur, Malaysia, June 2008.

[10] V. M. Sooraj, "Effect of palm oil fuel ash (POFA) on strength properties of concrete," International Journal of Scientific \& Technology Research, vol. 3, no. 6, pp. 1-7, 2013.

[11] M. W. Hussin, A. I. Mohamed, A. Budiea, and K. Muthusamy, "Durability of high strength concrete containing palm oil fuel ash of different fineness," Malaysia Journal of Civil Engineering, vol. 21, no. 2, pp. 180-194, 2009.

[12] W. Kroehong, T. Sinsiri, and C. Jaturapitakkul, "Effect of palm oil fuel ash fineness on packing effect and pozzolanic eaction of blended cement paste," Procedia Engineering, vol. 14, pp. 361369, 2011.

[13] M. A. M. Johari, A. M. Zeyad, N. M. Bunnori, and K. S. Ariffin, "Engineering and transport properties of high-strength green concrete containing high volume of ultrafine palm oil fuel ash," Construction and Building Materials, vol. 30, pp. 281-288, 2012.

[14] N. Ranjbar, M. Mehrali, A. Behnia, U. J. Alengaram, and M. Z. Jumaat, "Compressive strength and microstructural analysis of fly ash/palm oil fuel ash based geopolymer mortar," Materials and Design, vol. 59, pp. 532-539, 2014.

[15] B. Joglekar and R. M. Mourya, "Design, construction and testing open circuit low speed wind tunnel," International Journal of Engineering Research and Reviews, vol. 2, no. 4, pp. $1-9,2014$.

[16] T. T. Ghebrab, Development of Structure-Property Relationships for Hydrated Cement Paste, Mortar and Concrete, ProQuest, 2008.

[17] A. A. Ramezanianpour, "Fly ash," in Cement Replacement Materials: Properties, Durability, Sustainability, Springer Geochemistry/Mineralogy, pp. 47-156, Springer, New York, NY, USA, 2014. 
[18] H. U. Jamo, M. Z. Noh, and Z. A. Ahmad, "Structural analysis and surface morphology of a tretaed palm oil fuel ash," in Proceedings of the Seminar Kebangsaan Aplikasi Sains dan Matematik (SKASM '13), pp. 65-70, Batu Pahat, Malaysia, 2013. 

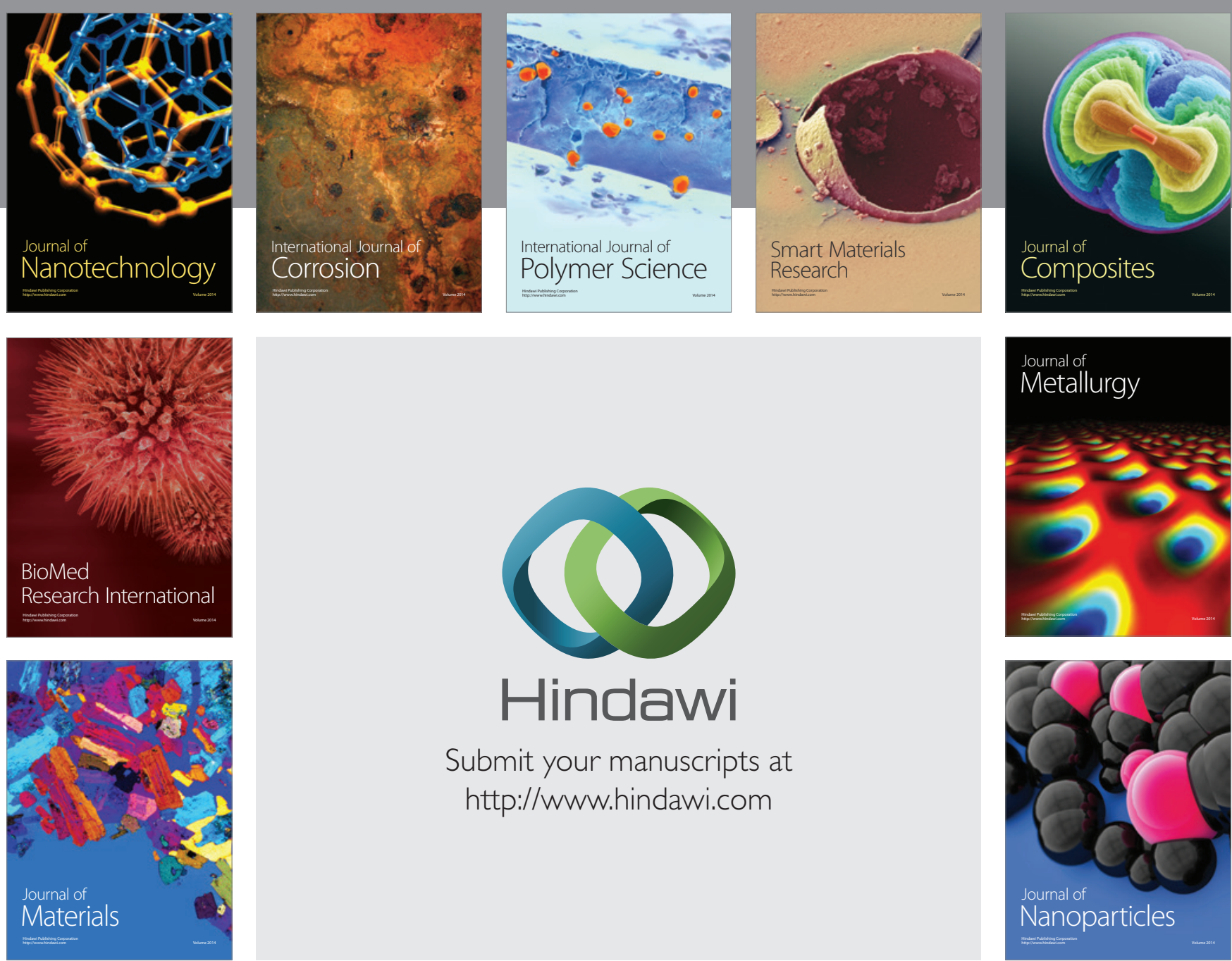

\section{Hindawi}

Submit your manuscripts at

http://www.hindawi.com

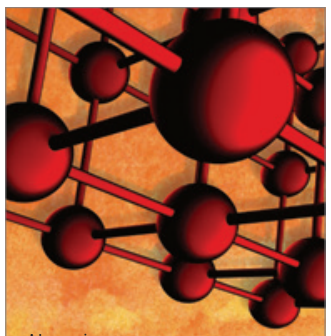

Materials Science and Engineering
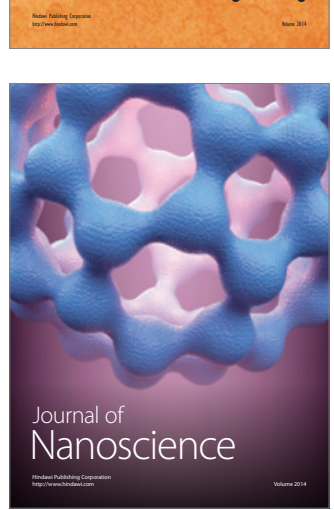
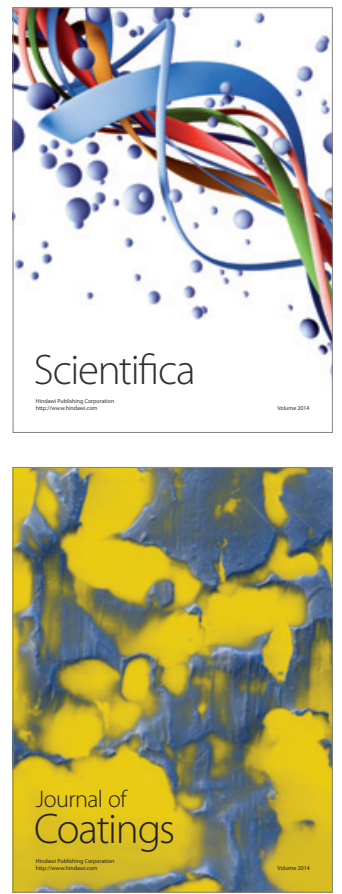
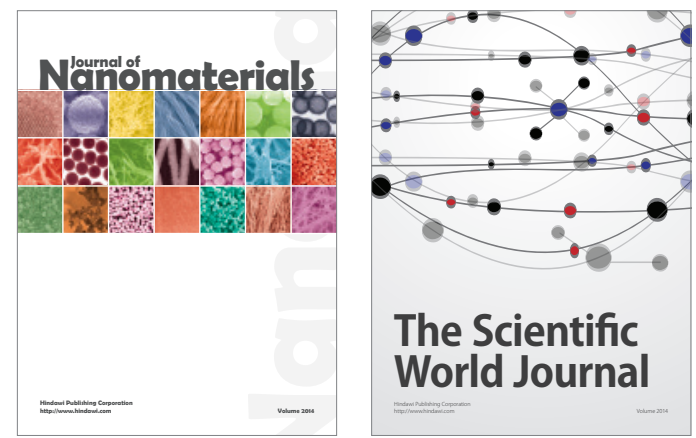

The Scientific World Journal
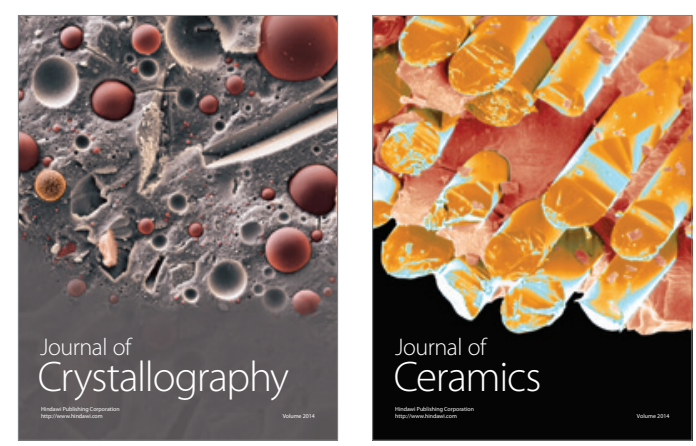
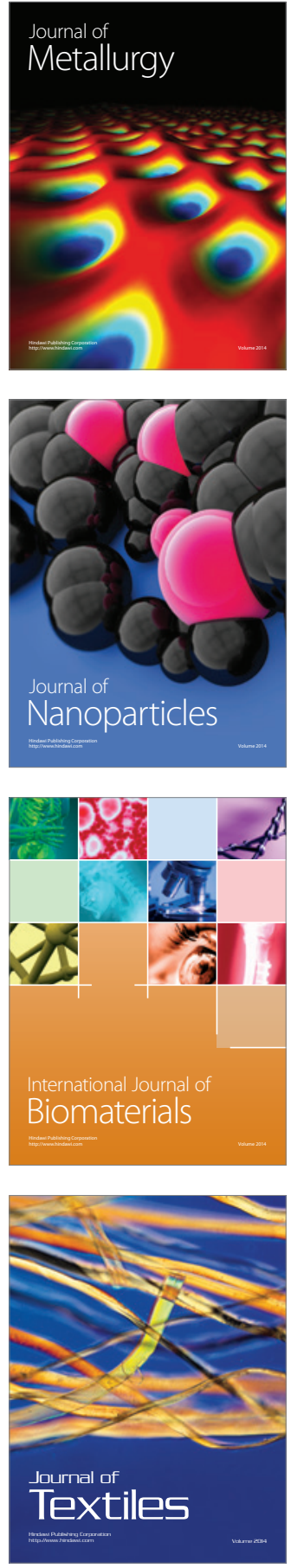